\title{
PENERAPAN METODE PARTIAL LEAST SQUARE REGRESSION (PLSR) PADA KASUS SKIZOFRENIA
}

\author{
Ni Wayan Ari Sundari ${ }^{1 \S}$, I Gusti Ayu Made Srinadi ${ }^{2}$, Made Susilawati ${ }^{3}$ \\ ${ }^{1}$ Program Studi Matematika Fakultas MIPA - Universitas Udayana [Email: arisundari93@ gmail.com] \\ ${ }^{2}$ Program Studi Matematika Fakultas MIPA - Universitas Udayana [Email: srinadi@unud.ac.id] \\ ${ }^{3}$ Program Studi Matematika Fakultas MIPA - Universitas Udayana [Email: $\underline{\text { mdsusilawati@unud.ac.id] }}$ \\ ${ }^{\S}$ Corresponding Author
}

\begin{abstract}
Partial Least Square Regression (PLSR) is a method that combines principal component analysis and multiple linear regression, which aims to predict or analyze the dependent variable and more than one independent variable. The purpose of this study is to determine the equation model for the recurrence of schizophrenia patients using the PLSR method. The best number of components to form a PLSR model in this study is one component with a minimum RMSEP value of 0.6094 and an adjR $R^{2}$ value of 80.09 percent.
\end{abstract}

Keywords: AdjR2, Partial Least Square Regression (PLSR), RMSEP, Schizophrenia Patients

\section{PENDAHULUAN}

Gangguan mental merupakan keadaan dimana seseorang tidak mampu mengenali kemampuannya, tidak mampu mengatasi tekanan hidup, hingga tidak mampu menjalani hidupnya dengan tenang. Salah satu gangguan mental yang cukup banyak terjadi di Indonesia yaitu Skizofrenia (WHO, 2003).

Skizofrenia merupakan gangguan mental yang disebabkan oleh kurangnya konsentrasi neurotransmitter pada otak, yang ditandai dengan gangguan terhadap pemahaman diri, menarik diri dari orang lain, disertai dengan halusinasi, delusi dan gangguan pikiran (Carr, 2003). Menurut Riset Kesehatan Dasar (Rikesdas) pada tahun 2018, penyebaran prevalensi gangguan skizofrenia yang terdapat di Provinsi Bali yaitu sebesar 3,0 per 1000 rumah tangga. Prevalensi di Provinsi Bali merupakan prevalensi tertinggi setelah Provinsi Daerah Istimewa Yogyakarta. Banyak penderita skizofrenia tidak mendapatkan penanganan yang tepat sehingga mengakibatkan kekambuhan pada waktu tertentu. Beberapa faktor yang dapat memengaruhi kekambuhan pada penderita skizofrenia diantaranya kepatuhan dalam mengonsumsi obat, keteraturan dalam pemeriksaan ke dokter, dukungan dari keluarga dan masyarakat (Widodo, 2003).

Data pada kasus skizofrenia tersebut merupakan data microarray, dimana jumlah variabel bebas nya lebih banyak daripada jumlah penelitian. Salah satu metode yang dapat menyelesaikan kasus data microarray yaitu Partial Least Square Regression (PLSR). PLSR merupakan metode yang menggabungkan antara analisis komponen utama dengan analisis regresi berganda, yang bertujuan untuk memprediksi atau menganalisis variabel terikat dengan lebih dari satu variabel bebas (Abdi, 2007). Penelitian sebelumnya mengenai PLSR telah dilakukan oleh Wijayanti (2018) pada dampak pembangunan dengan memperoleh nilai koefisien determinasi sebesar $95.78 \%$.

Berdasarkan uraian latar diatas, penulis menggunakan metode PLSR dengan tujuan untuk memodelkan kekambuhan pada pasien skizofrenia.

\section{METODE PENELITIAN}

\subsection{Jenis dan Sumber Data}

Jenis data yang digunakan dalam penelitian ini merupakan data sekunder dari penelitian sebelumnya yaitu Indriyanti (2019). Data yang digunakan yaitu data pada Rumah 
Berdaya Denpasar pada tahun 2018 dengan jumlah data sebanyak sepuluh pengamatan pada pasien skizofrenia.

\subsection{Metode Analisis Data}

Langkah-langkah analisis yang dilakukan dalam penelitian ini adalah sebagai berikut:

1. Membagi data menjadi dua kelompok, yaitu kelompok pertama yang berisi tujuh pengamatan untuk penentuan komponen optimal dan kelompok kedua yang berisi tiga pengamatan untuk penentuan validasi.

2. Pada kelompok pertama, akan dilakukan proses penentuan banyaknya komponen yang ada dalam model, kemudian dipilih banyaknya komponen yang memiliki Root Mean Square Error of Prediction (RMSEP) minimum. Langkah-langkahnya yaitu sebagai berikut:

a. Mencari vektor pembobot dari $X$ dan $Y$ melalui pembentukan Singular Value Decomposition (SVD) dengan persamaan $S=X^{T} Y$.

b. Mencari vektor kolom dari score $X$ dan score $Y$ dengan menggunakan persamaan $t=X w=E w \quad$ dan $u=Y q=F q$.

c. Mencari normalisasi dengan vektor kolom yang diperoleh pada persamaan $\quad t=X w=E w$ menggunakan $t^{*}=\frac{1}{\sqrt{t^{T} t}} t$.

d. Mencari loading $X$ dan loading $Y$ dengan menggunakan persamaan $p=E^{T} t^{*}$ dan $q=F^{T} t^{*}$.

e. Setelah dimensi dari matriks $X$ dan $Y$ berkurang, dilanjutkan dengan mencari pendugaan komponen pertama dengan menggunakan persamaan $E_{n+1}=E_{n}-t^{*} p^{T}$ dan $F_{n+1}=F_{n}-t^{*} q^{T}$.

f. Menentukan koefisien pada komponen pertama dengan menggunakan persamaan $B=$ $R\left(T^{T} T\right)^{-1} T^{T} Y=R Q^{T}$.

g. Mencari nilai RMSEP pada model dengan menggunakan persamaan $R M S E P=\sqrt{\frac{\left(\sum_{i=1}^{n}\left(\widehat{y}_{l}-y_{i}\right)^{2}\right)}{n}}$.

h. Melakukan iterasi dari langkah $a$ sampai $g$ untuk membentuk komponen selanjutnya sehingga mendapatkan nilai RMSEP minimum. i. Mencari komponen kedua pembentukan SVD dengan matriks perkalian silang $E_{n+1}^{T} F_{n+1}$.

j. Membuat model PLSR dengan cara meregresikan komponen yang terbentuk terhadap $Y$.

3. Memeriksa kemampuan model dalam mengatasi masalah overfitting dengan cara menghitung nilai $R^{2}$ menggunakan persamaan $R^{2}=1-\frac{J K G}{J K T}$.

4. Melakukan proses validasi pada kelompok kedua.

\section{HASIL DAN PEMBAHASAN}

\subsection{Pembentukan Model Partial Least Square Regression (PLSR)}

Pada penelitian ini menggunakan data dengan sepuluh pengamatan pada pasien skizofrenia dan membagi menjadi dua kelompok. Kelompok pertama diambil sebanyak tujuh pengamatan yang digunakan untuk menentukan komponen optimal, dan kelompok kedua diambil sebanyak tiga pengamatan yang digunakan untuk menentukan validasi.

Data pada kelompok pertama yaitu berjumlah tujuh pengamatan akan dilakukan pembentukan komponen optimal yang dilihat dari nilai RMSEP minimum pada uji validasi silang yang dapat dilihat pada Tabel 1 .

Tabel 1. Nilai RMSEP

\begin{tabular}{|c|c|c|}
\hline Comps & CV & AdjCV \\
\hline Intercept & 1.005 & 1.005 \\
\hline 1 comps & 0.6094 & 0.5915 \\
\hline $\mathbf{2}$ comps & 0.6913 & 0.6496 \\
\hline 3 comps & 0.6788 & 0.6343 \\
\hline 4 comps & 0.6956 & 0.6472 \\
\hline 5 comps & 0.7144 & 0.6623 \\
\hline
\end{tabular}

Sumber: Data diolah (2020)

Pada Tabel 1 dijelaskan bahwa komponen optimal yang dilihat dari RMSEP minimum yaitu satu komponen dengan nilai cross validation $(\mathrm{CV})$ sebesar 0.6094 . Hal ini berarti bahwa model yang akan digunakan yaitu model dengan satu komponen. Kemudian dilakukan penentuan nilai koefisien dari variabel bebas pada satu komponen. Adapun nilai koefisien dari masing-masing variabel bebas yaitu sebagai berikut: 


$$
\begin{array}{rl}
w_{1}=0.12341 & 727 x_{1}+0.18322867 x_{2} \\
& +0.18322867 x_{3} \\
& +0.05093751 x_{4} \\
& +0.04723813 x_{5} \\
& +0.03272521 x_{6} \\
& +0.19047753 x_{7} \\
& +0.11851423 x_{8} \\
& +0.01396305 x_{9} \\
& +0.22964315 x_{10}
\end{array}
$$

Untuk membentuk model PLSR, dilakukan dengan meregresikan $w_{1}$ terhadap variabel terikat $(Y)$, sehingga diperoleh model PLSR dari data kekambuhan pada pasien skizofrenia sebagai berikut:

$$
\begin{aligned}
\hat{Y}=-0.3379+ & 0.12341727 x_{1} \\
& +0.18322867 x_{2} \\
& +0.18322867 x_{3} \\
& +0.05093751 x_{4} \\
& +0.04723813 x_{5} \\
& +0.03272521 x_{6} \\
& +0.19047753 x_{7} \\
& +0.11851423 x_{8} \\
& +0.01396305 x_{9} \\
& +0.22964315 x_{10}
\end{aligned}
$$

\subsection{Koefisien Determinasi $\left(R^{2}\right)$}

Nilai koefisien determinasi $\left(R^{2}\right)$ yang diperoleh pada model PLSR yaitu 0.8340 atau 83.40\% yang berarti bahwa model PLSR yang telah diperoleh mampu menjelaskan keragaman persentase kekambuhan pada penderita skizofrenia sebesar $83.40 \%$ dengan variabel lain dijelaskan sisanya di luar model.

\subsection{Uji Validasi}

Setelah membentuk model PLSR, selanjutnya dilakukan uji validasi untuk menunjukan apakah model PLSR yang diperoleh valid atau tidak, dengan menggunakan data pada kelompok kedua. Nilai dari uji validasi pada data kelompok kedua diperoleh sebagai berikut:

Tabel 2. Hasil Uji Validasi

\begin{tabular}{|c|c|c|}
\hline Pengamatan & $\boldsymbol{Y}$ & $\widehat{\boldsymbol{Y}}_{\text {PLSR }}$ \\
\hline 8 & 3.044 & 2.60216 \\
\hline 9 & 3.044 & 2.762062 \\
\hline 10 & 3.044 & 2.888805 \\
\hline
\end{tabular}

Sumber: Data diolah (2020)

Pada Tabel 2 dijelaskan bahwa data kelompok kedua sebagai uji validasi dengan tiga pengamatan, diperoleh nilai $Y_{P L S R}$ dengan menggunakan persamaan $Y$. Nilai RMSEP yang diperoleh yaitu sebesar 0.24869 . Nilai $Y$ dan $Y_{P L S R}$ memiliki selisih nilai yang kecil, sehingga dapat dilihat bahwa nilai presisi antara $Y$ dan $Y_{P L S R}$ tidak jauh berbeda. Hal ini menunjukan bahwa model PLSR yang diperoleh baik dalam memodelkan kekambuhan pada pasien skizofrenia.

\section{KESIMPULAN DAN SARAN}

Berdasarkan penerapan metode PLSR yang menggunakan data kekambuhan pada pasien skizofrenia di Provinsi Bali pada tahun 2018, diperoleh beberapa kesimpulan, diantaranya sebagai berikut:

1. Model PLSR pada data kelompok pertama dengan komponen optimal sebanyak 1 komponen dinyatakan dengan persamaan:

$$
\begin{aligned}
\hat{Y}=-0.3379+ & 0.12341727 x_{1} \\
& +0.18322867 x_{2} \\
& +0.18322867 x_{3} \\
& +0.05093751 x_{4} \\
& +0.04723813 x_{5} \\
& +0.03272521 x_{6} \\
& +0.19047753 x_{7} \\
& +0.11851423 x_{8} \\
& +0.01396305 x_{9} \\
& +0.22964315 x_{10}
\end{aligned}
$$

2. Nilai koefisien determinasi $\left(R^{2}\right)$ diperoleh sebesar 0.8340 atau $83.40 \%$ dengan variabel lain dijelaskan sisanya di luar model.

3. Nilai RMSEP pada data kelompok kedua yaitu uji validasi sebesar 0.24869. Hal ini berarti bahwa prediksi model PLSR yang diperoleh baik dalam memodelkan kekambuhan pada pasien skizofrenia.

Adapun saran yang dapat diberikan kepada peneliti lainnya ingin melanjutkan penelitian mengenai PLSR, diharapkan menggunakan lebih banyak informasi untuk mendukung kejelasan pada data. Selain itu, peneliti juga dapat mengembangkan penelitian ini menggunakan metode Least Absolute Shrinkagge and Selection Operator (LASSO).

\section{DAFTAR PUSTAKA}

Abdi, H. (2007). Partial Least Square Regression. Encyclopedia of Measurement and Statistics, Volume II, pp. 740-744. 
Carr, A. (2003). Abnormal Psychology. USA:

Taylor \& Francis e-Library.

Idaiani, S. (2019). Prevalensi Psikosis di Indonesia berdasarkan Riset Kesehatan Dasar 2018. Jurnal Penelitian dan Pengembangan Pelayanan Kesehatan Vol 3, No 1, 9-16.

Indriyanti, I. (2019). Analisis Kekambuhan Orang Dengan Skizofrenia Menggunakan Metode Partial Least Square Structural Equation Model. Journal, Bali; Universitas Udayana.

Widodo, A. (2003). Keperawatan Jiwa 1. Surakarta: Surakarta FIK UMS.

Wijayanti, N. S. (2018). Penerapan Partial Least Square Regression (PLSR) Pada Dampak Pembangunan di Provinsi Bali. Journal, Bali: Universitas Udayana.

World Health Organization (WHO). (2003). Investing in Mental Health. Swithzerland: Departement of Mental Health and Substance Dependence. 